EDMUND KOWALSKI CSSR

Academia Alfonsiana w Rzymie

https://orcid.org/0000-0002-1406-0659

\title{
TOWARZYSZENIE OSOBIE UMIERAJĄCEJ PRZEZ RODZINĘ. ETYKA KOŃCA ŻYCIA
}

W dramatycznym i tragicznym w skutkach kontekście pandemii przedmiotem naszej refleksji nie będzie jednak ,,problem umierania” w aspekcie społecznym, politycznym i ekonomicznym w skali światowej, europejskiej czy ogólnopolskiej, lecz „proces umierania” kogoś bliskiego przeżywany przez niego samego, jego rodzinę i personel medyczno-sanitarny ${ }^{1}$. Wskazany powyżej cel wytycza dwa podstawowe wymiary niniejszego opracowania - psychologiczny i antropologiczno-etyczny. W tej perspektywie zostaną opisane reakcje pacjenta i jego rodziny w obliczu zbliżającej się śmierci (aspekt psychologiczny), a następnie wskazane zostaną fundamentalne kryteria moralne działań ludzkich wobec osoby umierającej, aby wyrażały one niezbywalną godność ludzką (aspekt antropologiczno-etyczny). „Humanizować śmierć" człowieka nie oznacza uciekać od niej, zakrywać ją czy banalizować (czego przykładem jest choćby Halloween), lecz wprost przeciwnie, oznacza uczynić z niej rzeczywistość ludzką, ponieważ stanowi ona istotną część życia człowieka. Wymiary, do których zdąża i które angażuje taki proces, są rzeczywistościami „do uczynienia" lub ,ponownego uczynienia” ludzkimi, albowiem obecnie takimi nie są, a w niedalekiej przyszłości mogą być całkowicie pozbawione swego głębokiego sensu personalnego i ludzkiego (rosnące tendencje proeutanazyjne).

\section{REAKCJE PACJENTA W OBLICZU PERSPEKTYWY ŚMIERCI}

Reakcja psychologiczna człowieka w obliczu śmierci stała się przedmiotem studium doktor psychologii Elisabeth Kübler-Ross (1926-2004). Opublikowana przez nią książka Śmierć $i$ umieranie (On death and dying, przethumaczona na

1 Por. E. Kowalski, Osoba i bioetyka. Zagadnienia biomedyczne dla duszpasterzy i katechetów, Kraków: Homo Dei 2009, s. 331-344. 
czterdzieści trzy języki świata) $)^{2}$ opisuje jej długoletnie doświadczenia przy łóżkach ludzi umierających w szpitalu Billings w Chicago ${ }^{3}$. To doświadczenie, zreferowane poniżej w syntetycznym skrócie, pozwoliło jej na wyróżnienie pięciu podstawowych „etapów umierania”, do których odwołują się inni autorzy podejmujący wielowymiarowe zagadnienie dotyczące końca życia ${ }^{4}$ oraz założona przez nią fundacja ${ }^{5}$. Innymi słowy, chodzi o dynamiczny i sprecyzowany układ stanów, ze specyficznymi rodzajami reakcji, które nie zawsze następują po sobie w porządku chronologicznym i z tą samą intensywnością, ale które w mniejszym lub większym stopniu są ujawniane przez człowieka w obliczu nieuniknionej śmierci':

1. Odrzucenie i odosobnienie (denial and isolation). Pierwszy etap ,procesu umierania" charakteryzuje się psychicznym mechanizmem negacji. Dramatyczna wiadomość o nieuleczalnej chorobie lub o bliskiej śmierci powoduje strach i panikę. W tej niespodziewanej sytuacji człowiek szuka dróg wyjścia, chwyta się nawet najmniej prawdopodobnych nitek nadziei: błąd diagnostyczny, nieobecność niektórych

2 Pierwotne dzieło (1969) autorka przeredagowała i zostało ono wydane wielokrotnie jako: On Death and Dying: What the Dying Have to Teach Doctors, Nurses, Clergy and Their Own Families, London and New York: Routledge. Taylor \& Francis Group 2009. Podobne badania podjęli profesorowie i studenci z Università Vita-Salute San Raffaele w Mediolanie. Por. C.G. Vella, L'etica a servizio della persona malata. Esperienze e riflessioni maturate al San Raffaele di Milano, Milano: Edizioni Paoline 2007.

3 E. Kübler-Ross, La morte e il morire, Assisi: Cittadella ${ }^{15} 2009$; por. inne publikacje E. Kübler-Ross: La morte e la vita dopo la morte. "Morire è come nascere", Roma: Edizioni Mediterrane 2007; Impara a vivere impara a morire. Riflessioni sul senso della vita e sull'importanza della morte, Milano: Armenia 2001; La morte è di vitale importanza. Riflessioni sul passaggio dalla vita alla vita dopo la morte, Milano: Armenia 1997; Vivi ora e oltre la morte, Roma: Edizioni Mediterrane 2016; Sulla vita dopo la morte, Torino: Edizioni L'Età dell'Acquario 2018; Lezioni di vita. Ciò che la morte e il morire ci insegnano sulla vita e sul vivere, Torino: Edizioni L'Età dell'Acquario 2019; Rozmowy o śmierci i umieraniu, tłum. I. Doleżal-Nowicka, Poznań: Wydawnictwo Media Rodzina 1998; (z D. Kessler) Lekcje życia, thum. K. Pułaski, Poznań: Wydawnictwo Media Rodzina 2014; Pytania i odpowiedzi na temat śmierci i umierania. Odpowiedzi na najczęściej zadawane pytania dotyczące śmierci, tłum. K. Sobiepanek-Szczęsna, Warszawa: MT Biznes 2010; Śmierć. Ostatni etap rozwoju, tłum. K. Sobiepanek-Szczęsna, Warszawa: MT Biznes 2019.

4 Por. G.S. Belkin, Death before Dying, Oxford-New York: Oxford University Press 2014; M. Niemiec, Aspekty etyczne dotyczace konca życia. Ethical aspects of the end of life, „Medycyna Paliatywna w Praktyce" 10 (2016), nr 1, s. 1-7; T. Dzierżanowski, J. Binnebesel, Godność w umieraniu, „Medycyna Paliatywna” 11 (2019), nr 4, s. 156-162.

5 Por. EKR Foundation, https://www.ekrfoundation.org/ [dostęp: 7 V 2021]. Association EKR France, https://www.ekr-france.fr/ [dostęp: 7 V 2021]. W ankiecie magazynu „Time” E. Kübler-Ross znalazła się w gronie „stu najbardziej wpływowych myślicieli dwudziestego wieku”. W latach siedemdziesiątych została najpierw w 1977 roku Kobietą Roku, a następnie Kobietą Dziesięciolecia w dziedzinie nauki. Jej archiwum znajduje się w dziale zbiorów specjalnych na Uniwersytecie Stanforda, gdzie wspomaga zwłaszcza naukowców i studentów zajmujących się opieką paliatywną (zob. Stanford Center for Biomedical Ethics, https://med.stanford.edu/bioethics/events/elisabeth-kubler-ross-archive.html [dostęp: 7 V 2021]).

6 Por. E. Kübler-Ross, La morte e il morire, s. 50-175. 
kluczowych symptomów choroby, konfrontacja z innymi doświadczeniami itp. Stałe odrzucanie prawdy (nieuleczalna choroba, bliskość śmierci) powoduje zamknięcie się w sobie i niechęć do kontaktów z innymi ludźmi.

2. Gniew i bunt (anger). Po przezwyciężonym pierwotnym strachu następuje etap poszukiwania racjonalnych dróg wyjścia. Po pierwsze, człowiek odkrywa, że postawiona diagnoza nie była omyłkowa, symptomy choroby są takie, jakie powinny być, i w tym wypadku lekarz miał rację. Horyzont nadziei kurczy się, a nieunikniony koniec jest obecny w całej swej nieodwołalności. Progresywne odrzucanie tego ostatecznego faktu przeradza się w odrzucanie wszystkiego, co otacza człowieka przeżywającego ten stan: rodziny, personelu sanitarno-medycznego, Boga. Pogarda, cynizm i bunt następują po sobie i nakładają się na siebie, prowokując pragnienie wyizolowania się, które w rzeczywistości jest tylko strachem przed własną samotnością.

3. Kompromisy i pakty (bargaining). Po wyczerpaniu się tych bardzo emocjonalnych reakcji przychodzi etap względnej równowagi. Pacjent „podpisuje” niewidzialne pakty i zgadza się na kompromisy z sobą samym i z własnym cierpieniem: poszukuje odroczeń decyzji na później, wiedząc, że pozostało mu jeszcze trochę czasu. W tym stanie, z jednej strony, szuka się innych dróg wyjścia: poliklinika bardziej wyspecjalizowana, inny i bardziej doświadczony lekarz; z drugiej strony, porządkuje się swoje sprawy personalno-rodzinne: myśli się o współmałżonku i dzieciach, daje się rady dotyczące swojej pracy lub organizuje się to, co w przyszłości powinno być dokończone.

4. Depresja (depression). Względna równowaga, niestety, nie trwa długo. W tym wypadku nie może być inaczej, skoro chodzi jedynie o prowizoryczny kompromis pomiędzy racjami rozumowymi i tymi czysto emotywnymi (uczucie strachu, panika, gniew, bunt). Pacjent zamyka się w sobie i zagłębia się w swoim „ja”. Obraz własnego końca, wizja bólu i cierpień ukochanej rodziny czy przypuszczenia, jak czują się inni w analogicznej sytuacji, są wszechobecne w myślach człowieka umierającego z całą swoją okrutną brutalnością, zamykając go w nieprzeniknionej ciemności, w której nie potrafi on na razie dostrzec żadnego światła.

5. Akceptacja (acceptance). Zwycięski po długiej walce lub tylko pobity przez własną niemożność, schorowany człowiek odnajduje w końcu drogę prowadzącą do akceptacji danego stanu rzeczy. Akceptacja ta nie zawsze jest silna, jasna i w pełni odpowiedzialna. Często jest jedynie pogodzeniem się z losem w obliczu nieuniknionej rzeczywistości lub efektem zmęczenia $\mathrm{w}$ daremnej walce $\mathrm{z}$ niewidzialnym wrogiem. W wyjątkowych przypadkach akceptacja jest prawdziwym wyrazem przyjęcia tego, co ma przyjść, a nie etapem, do którego się zdąża.

Wyszczególnione tu i pokrótce opisane etapy, które przeżywają ludzie w obliczu dramatycznych faktów końca życia (wielkie cierpienie fizyczne i duchowe, nieuleczalna choroba, śmierć), w języku psychologii nazwane są mechanizmami obronnymi, tj. reakcjami w obliczu sytuacji ekstremalnie trudnych. Rodzaj, długotrwałość czy intensywność tych reakcji zależy od wielu czynników wewnętrznych 
(temperament, charakter, stan sumienia czy „urobienia duchowego") i zewnętrznych (wychowanie w rodzinie, stosunek do Boga i do innych, uwarunkowania kulturowe). Jedno jest pewne, jak podkreśla E. Kübler-Ross: podczas wszystkich tych etapów pozostaje zawsze obecna nadzieja. Jeśli pacjent w fazie choroby terminalnej przestaje mówić o nadziei, jest to zwykle znak bliskiej i nieuniknionej śmierci. Na ten stan bez wyrażanej już nadziei wskazują specyficzne stwierdzenia: „myślę, że przyszedł już koniec”, „sądzę, że to już” lub ,jestem gotowy i nawet się nie boję”. Wszyscy powyżej cytowani chorzy umierają przed upływem dwudziestu czterech godzin?

\section{REAKCJE RODZINY W OBLICZU PERSPEKTYWY ŚMIERCI}

W procesie dojrzewania i przygotowania się na własną śmierć, pełnym wewnętrznej walki i nadziei, z końcową akceptacją jej nieuniknioności, E. Kübler-Ross wskazuje na istniejące „konflikty”, które pochodzą z dwóch podstawowych źródeł. Pierwszym z nich jest brak jakiejkolwiek nadziei przekazywanej osobie chorej przez personel lub rodzinę wtedy, kiedy najbardziej jej potrzebowała. Drugie źródło konfliktów stanowi „niemożność” zaakceptowania lub brak zrozumienia przez rodzinę finalnej fazy życia przeżywanej przez chorego. W tym kontekście bardzo pożytecznym doświadczeniem egzystencjalnym i pedagogicznym będzie powrót do wyszczególnionych wcześniej ,etapów umierania” w celu przeanalizowania ich z punktu widzenia zachowań rodziny. Retrospektywa - jak się wydaje - pozwoli nakreślić podstawowe kryteria prawidłowych i bardziej odpowiedzialnych zachowań wobec osób stojących w obliczu nieuniknionej śmierci. Następnie umożliwi inne spojrzenie na nasz stosunek do problemu śmierci celem pomocy osobie chorej i jej rodzinie we wzajemnym synchronizowaniu ich potrzeb i we wzajemnej akceptacji nieuniknionej rzeczywistości: ,już umierać - jeszcze żyć".

\subsection{ETAP ODRZUCENIA I ODOSOBNIENIA}

Bardzo wcześnie, zanim jeszcze zaistnieje pierwsza faza związana z uświadomieniem sobie, że jestem nieuleczalnie chory lub bliski śmierci (etap odrzucenia i odosobnienia), wskazane jest, według E. Kübler-Ross, podejmowanie istotnych egzystencjalnych tematów w rodzinie, zwłaszcza z osobami w starszym wieku lub z tymi, które dopiero zachorowały, celem wspólnego przygotowywania się do stanięcia w obliczu nowych rzeczywistości: choroby, cierpienia i śmierci. Odkładanie

7 Por. E. Kübler-Ross, La morte e il morire, s. 156-158. 
takich rozmów ad Kalendas Graecas nie służy osobie chorej, ponieważ przyczynia się do powstawania mechanizmów obronnych (zamykanie się w sobie, niepotrzebny gniew czy bunt), a może też zabraknąć czasu na takie świadome przygotowanie (głęboka depresja, brak oznak kontaktu $\mathrm{z}$ otoczeniem). Zwykle odrzucenie jest tymczasowym mechanizmem obronnym. W tej pierwszej fazie chorzy mogą sporadycznie mówić o swym aktualnym stanie zdrowia, a następnie niespodziewanie przejawiać niezdolność do realistycznej oceny swojej sytuacji (fantazje na temat realizacji najbardziej nieprawdopodobnych marzeń, pragnień). Potrzeba odrzucania istnieje u każdej osoby na początku doświadczania ciężkiej choroby, bardziej niż przy końcu życia. Na tym etapie trzeba zwrócić szczególną uwagę na trzy podstawowe elementy: sposób, w jaki jest informowana osoba chora; ile czasu pozostało jej do dyspozycji w celu stopniowego zdania sobie sprawy z nieuniknionego faktu śmierci; jak przygotowywała się do tego końcowego aktu podczas swojego życia, aby w sposób pozytywny sprostać wymogom dramatycznych sytuacji egzystencjalnych. Tylko ten, kto stoi przy łóżku umierającej osoby i umie wrażliwie słuchać, może wyjść naprzeciw jej potrzebom: pomóc jej otworzyć się, wyjść z wewnętrznej izolacji i rozmawiać otwarcie o tym wszystkim, co w tym momencie przeżywa. Chorzy są bardzo wybredni w wyborze osób z rodziny czy z personelu medycznego, z którymi mogliby bez większych przeszkód rozmawiać na temat swej choroby i śmierci, natomiast unikają szczególnie tych ludzi, którzy nie dopuszczają myśli o śmierci. Jeśli ci pierwsi zostają przy łóżku chorego, aby go słuchać, a następnie kontynuują swoje wizyty w szpitalu czy w domu osoby chorej, u tej ostatniej rodzi się i rozwija poczucie zaufania, bezpieczeństwa i wzajemnego zrozumienia. $\mathrm{Z}$ biegiem czasu chorzy otwierają się i opowiadają o tym, co w danym momencie przeżywają, komunikując swoją samotność i potrzebę wsparcia za pomocą nie tyle słów (w wielu wypadkach chodzi o obecność), ile małych gestów (uśmiechu przywitania, przytrzymania przyjaznej dłoni, łez z powodu chwilowego rozstania). Sposób bycia z osobami chorymi czy w podeszłym wieku wymaga od kontaktujących się z nimi bardzo wnikliwego przeanalizowania własnych reakcji, ponieważ odbijają się one na sposobie odreagowania przez chorych i mogą być pozytywnym lub negatywnym wkładem $\mathrm{w}$ ich proces przygotowania się do podjęcia ostatecznych decyzji. Szczere przeegzaminowanie siebie przez osoby towarzyszące chorym czy starszym, którymi się opiekują, może być wielką pomocą nie tylko dla podopiecznych, ale przede wszystkim dla własnego wzrostu opiekunów i ich dojrzewania w człowieczeństwie ${ }^{8}$.

8 Por. E. Kübler-Ross, La morte e il morire, s. 50-62. 


\subsection{ETAP GNIEWU I BUNTU}

Pierwszy etap odrzucenia i odosobnienia nie może trwać zbyt długo, zostaje zastąpiony przez uczucia gniewu, zazdrości i resentymentu. W przeciwieństwie do pierwszej fazy ta następna, częstego popadania w gniew, jest bardzo trudna dla rodziny czy personelu medycznego. Podstawowa przyczyna takiego typu zachowania tkwi w chorych, którzy na razie nie potrafią sobie poradzić z nową i tragiczną dla siebie sytuacją (wiadomość o nieuleczalnej chorobie, bliskość śmierci) i dlatego swój gniew przenoszą na otaczające ich środowisko. Według nich, lekarze i pielęgniarki nie umieją leczyć, nie znają się na analizach medycznych lub wykonują tylko to, co zwykły człowiek może sam zrobić bez ich pomocy. Przedstawiciele rodziny są przyjmowani przez nich chłodno lub z nieukrywaną obojętnością, co wprawia ich w zakłopotanie i czyni wizytę nieznośną. Odpowiadają więc bólem, łzami i poczuciem winy czy wstydu albo po prostu unikają wizyt, a wielu z nich już nie powróci do szpitala. To zachowanie rodziny zwiększa częstotliwość i intensywność sprzeczek wywołanych przez chorego oraz wyzwala jego gniew. W tym bardzo trudnym dla niego okresie niewiele osób z najbliższego otoczenia stwierdza E. Kübler-Ross - stara się wejść w sytuację chorego celem zrozumienia jego co najmniej dziwnego i niepojętego zachowania (zdolność empatii). Te osoby z rodziny, które nie zastanawiają się nad przyczynami gniewu i buntu ze strony swego krewnego, w konsekwencji odbierają te zachowania bardzo osobiście: na jego gniew odpowiadają jeszcze większą złością. Uzasadnieniem tego typu reakcji z ich strony jest ,agresywność” osoby chorej czy w podeszłym wieku. Oczywiście, mogą unikać wizyt czy skracać czas ich trwania, mogą prowadzić zbyteczne rozmowy o niczym, ale nie zrozumieją nigdy prawdziwej przyczyny braku właściwej komunikacji między sobą a chorym. Osoba chora, którą obdarza się należnym szacunkiem, którą chce się zrozumieć (tymczasowe tolerowanie racjonalnego czy irracjonalnego gniewu) i której poświęci się więcej uwagi i czasu (w celu wypowiedzenia się, lepszego zrozumienia, otrzymania pociechy), szybko „spuści z tonu” oraz zmniejszy ilość skarg i zażaleń. Tę trudną formę pomocy przedstawiciele rodziny mogą świadczyć jedynie pod warunkiem opanowania własnego strachu przed chorobą i śmiercią. Uświadomienie sobie własnych mechanizmów obronnych i stałe ich kontrolowanie wpłynie pozytywnie na sposób traktowania osoby chorej czy starszej przez jej rodzinę. Również chory zauważy od razu, że nawet w tym tak bardzo trudnym dla niego okresie jest ktoś, kto go akceptuje i kocha takim, jaki jest teraz. Nawet milcząca obecność jako widomy znak uszanowania i troski o ukochaną osobę, która w tym momencie jest bardzo chora, będzie wielkim gestem wskazującym, że jest się słuchanym, bez potrzeby gniewania się, w celu otrzymania tego, co się należy ze strony rodziny'.

9 Por. E. Kübler-Ross, La morte e il morire, s. 63-96. 


\subsection{ETAP ZGODY NA KOMPROMISY I ZAWIERANIE PAKTÓW}

Trzeci etap, w postaci szukania kompromisów i zawierania „niepisanych paktów", może być również korzystny dla osoby chorej, choć trwa tylko przez bardzo krótkie okresy. Zawieranie pewnego rodzaju ,paktów zgody”, z Bogiem i z ludźmi, ujawnia pragnienie przedłużenia życia, poprzedzone pragnieniem bycia przynajmniej przez kilka dni czy godzin uwolnionym od nieznośnego bólu i fizycznych ograniczeń, spowodowanych przez postępującą ciężką chorobą. Zgadzanie się na kompromisy jest w rzeczywistości próbą odroczenia końcowego aktu przez chorego. Zawiera on swego rodzaju pakt: jeśli będę się dobrze zachowywał i nie będę się już więcej gniewał, zostanę nagrodzony (uwolniony od cierpień, moje życie zostanie przedłużone). Paradoksalnie, żaden z chorych nie dotrzymuje tych „umów”. Obietnice czynione przez chorych w bliskości śmierci są, zdaniem E. Kübler-Ross, ściśle związane z jakąś ukrytą winą i nie mogą być lekceważone przez personel medyczny, a zwłaszcza przez kapelana i rodzinę. Wrażliwe wsłuchiwanie się w to, co wyznaje chory, może doprowadzić do odkrycia, czy osoba chora naprawdę czuje się winna popełnienia wielkiego zła, czy po prostu są to jedynie nieuświadomione, głębokie i nieprzyjazne pragnienia, które przeradzają się w rodzaj winy. Cierpliwe towarzyszenie osobom schorowanym bądź w podeszłym wieku w tym stanie polegałoby na dotarciu do źródła prawdziwej lub urojonej winy w celu uwolnienia ich od jej niszczącej siły ${ }^{10}$.

\subsection{ETAP PRZEŻYWANIA DEPRESJI}

Kiedy nieuleczalnie chory nie może już negować swojej choroby, tym bardziej nie może być swobodny i uśmiechnięty. Reakcje odrzucania, izolacji i gniewu zostaną szybko zastąpione przez fakt poważnych strat zdrowotnych, które następują jedna po drugiej. Mogą one przybrać różne formy: fizyczne (trwała utrata zdrowia, zniekształcona sylwetka czy twarz), psychologiczne (poczucie nieużyteczności czy niebycia już kobietą lub mężczyzną, głęboki smutek, poczucie winy), egzystencjalne (utrata sensu życia, szacunku do siebie, pracy lub dóbr, które odkładało się na starość). Wskazane wyżej podstawowe przyczyny depresji są dobrze znane. Niemniej jednak tym, o czym często zapominają członkowie rodziny, jest cierpienie, które osoba chora czy starsza w obliczu śmierci musi przeżyć, przygotowując się do ostatecznej rozłąki z tym światem. W rezultacie należy mówić o dwóch typach depresji - reaktywnej i przygotowawczej. W pierwszym przypadku chodzi o stan depresyjny wywołany jakąkolwiek znaczącą utratą, na przykład zdrowia, dóbr czy pracy. W tym okresie, przy takim rodzaju depresji rodzina może być dla chorego wielką pomocą, podejmując się organizacji życia w domu, zwłaszcza kiedy chodzi

10 Por. E. Kübler-Ross, La morte e il morire, s. 97-100. 
o pozostawione dzieci lub osoby starsze, które wymagają specjalnej opieki. Deklarowana przy łóżku chorego gotowość pomocy i jej widoczne efekty sprawią, że stan depresyjny u osoby chorej czy starszej zmniejszy się bardzo szybko i będzie ona ufnie patrzeć w niedaleką przyszłość oraz ze względnym spokojem oczekiwać ostatecznego rozstania.

Drugi typ depresji, zwany przygotowawczą, jest prowokowany przez przeżywanie utraty wszystkiego w bezpośredniej bliskości śmierci. Człowiek chory czy w podeszłym wieku jest świadom, że traci wszystkie osoby i rzeczy, które do tej pory kochał. Pozwolić mu wyrazić jego ból i żal w obliczu ostatniego rozstania znaczy być świadomym i wyrozumiałym dla powagi chwili i stanu przeżywanego przez umierającego. Ten rodzaj depresji ma zwykle charakter milczący. W tym stanie, kiedy droga i ukochana osoba przygotowuje się do ostatniej podróży, nie trzeba zbyt wielu słów. Ona oczekuje ze strony rodziny gestów miłości, przyjaźni i przywiązania. Delikatne gesty i bycie przy niej mówią więcej niż stałe wyrażanie żalu i smutku. Przede wszystkim jest to odpowiedni moment na wspólne przygotowanie się na śmierć poprzez modlitwę i wzajemne zrozumienie się celem przezwyciężenia oznak obaw, niepokoju czy rozpaczy. Pełna zrozumienia i wyczulenia asystencja duchowa ze strony rodziny pozwoli człowiekowi choremu czy starszemu umierać w stanie akceptacji i prawdziwego pokoju ${ }^{11}$.

\subsection{ETAP AKCEPTACJI}

Jeśli osoba chora czy w podeszłym wieku miała do dyspozycji wystarczająco dużo czasu i pomogło się jej w przezwyciężeniu wyżej opisanych „etapów umierania", osiągnie ona stan, w którym nie będzie już miejsca na depresję czy gniew wobec nieuniknionego przeznaczenia. Akceptacja faktu śmierci nie może być jednak utożsamiana ze „światłem szczęścia”. Jest ona niemal całkowicie pozbawiona uczuć i przede wszystkim jest czasem „ostatniego odpoczynku przed długą podróżą". W tym okresie należy bezwzględnie odróżnić pragnienie niektórych członków rodziny sztucznie forsowanego przedłużania życia osoby umierającej od pragnienia tej osoby „ostatniego odpoczynku” i umierania w pokoju. Jeśli bliscy nie umieją odróżnić tych dwóch stanów, czynią umierającemu więcej złego niż dobrego. Ponadto sfrustrowani z powodu swoich nieudanych wysiłków, przysparzają mu dodatkowych cierpień, prowokując niepotrzebne stany niepokoju czy wątpliwości. Rodzina musi zrozumieć, że ukochana osoba, która teraz umiera, doszła do tego ostatniego etapu swojego życia, kiedy śmierć jest jedynie wielką ulgą. Osoby chore czy w podeszłym wieku umierają z mniejszymi trudnościami wewnętrznymi, kiedy ich rodziny pozwolą i pomogą im w stopniowym pożegnaniu i oddalaniu się od tego wszystkiego, co je do tej pory absorbowało, wiązało czy wprost zniewalało.

11 Por. E. Kübler-Ross, La morte e il morire, s. 101-127. 
Przedstawiciele rodziny powinni sobie również uświadomić wielki wysiłek umierającego w osiągnięciu całkowitej akceptacji, prowadzącej do stanu stopniowego oddalania się (decathexis), w którym już nie ma miejsca na wzajemną komunikację. Istnieją, według E. Kübler-Ross, dwa podstawowe sposoby osiągnięcia takiego stanu. Osoby chore, zwłaszcza w podeszłym wieku, które osiągnęły stan dojrzałości psychoduchowej (wielkie znaczenie wiary w Boga), ponieważ dużo pracowały i cierpiały, dochowały się dorosłych dzieci i wykonały swoje podstawowe zadania życiowe, a tym samym znalazły fundamentalny sens swojego życia, będą umierać pogodnie i bez większych trudności (,jakie życie, taka śmierć" - powtarzał często św. Alfons Maria de' Liguori, 1696-1787 ${ }^{12}$. W tym wypadku nieobecne są etapy odrzucenia i odosobnienia, gniewu i buntu oraz stan depresyjny.

Wszystkie inne osoby mogą osiągnąć podobny stan fizyczny, psychiczny i duchowy pod warunkiem, że mają do dyspozycji wystarczająco dużo czasu. Te osoby, „mniej dojrzałe” z punktu widzenia rozwoju psychicznego, moralnego i duchowego, wymagają większej pomocy i zrozumienia ze strony swojego środowiska rodzinno-społecznego, ponieważ przeżywają wszystkie wcześniej opisane „etapy umierania" z większą lub mniejszą intensywnością. Jeśli jest obok ktoś (rodzina, kapelan, przyjaciel), kto im w tym umiejętnie pomoże, również one osiągną stan akceptacji i względnego spokoju ${ }^{13}$.

\section{ETYKA KOŃCA ŻYCIA: POMÓC W REALIZACJI SIEBIE JAKO „OSOBY DO SPEŁNIENIA”}

Oczywiście, adekwatna pomoc człowiekowi w obliczu śmierci wymaga podstawowych kompetencji natury psychologicznej, antropologicznej czy etycznej. Wzorcowe studium E. Kübler-Ross jest tego dobrym przykładem. Na zakończenie tej refleksji zostaną nakreślone istotne elementy „etyki końca życia”, które powinny pomóc w bardziej świadomym i odpowiedzialnym podejściu do mysterium mortis, przeżywanego $\mathrm{w}$ rodzinie i przede wszystkim $\mathrm{z}$ rodziną.

1. Postawa słuchania - jest z nią najwięcej problemów, choć wydawać by się mogło, że słuchanie powinno być czymś łatwym i naturalnym. Niestety, żyjemy w epoce obrazu, która prawie całkowicie zniszczyła naszą zdolność słuchania, zastępując ją bezsłownym patrzeniem. Telewizor czy komputer wyczerpują lub

12 Por. A.M. de' Liguori, Apparecchio alla morte cioè considerazioni sulle massime eterne, Cinisello Balsamo (Mi): Edizioni San Paolo 2011; A.M. de' Liguori, Przygotowanie do śmierci, thum. J. Serafin, Kraków: Homo Dei ${ }^{2} 2016$.

13 Por. E. Kübler-Ross, La morte e il morire, s. 128-155. Por. Z. Kępińska-Walczak, Recenzja ksiażki „Rozmowy o śmierci i umieraniu” autorstwa Elisabeth Kübler-Ross. Poznań 1998, wyd. Media Rodzina, „Warszawskie Studia Pastoralne” 19 (2013), s. 339-344. 
skutecznie zastępują naszą potrzebę komunikacji łatwej, szybkiej i przyjemnej, bez jakichkolwiek zobowiązań na dłuższy czas wobec innych (przyjaźń, miłość, rodzina). Nie chcemy, a przede wszystkim nie umiemy słuchać, ponieważ ta zdolność wymaga wyjścia naprzeciw potrzebom innych, zwłaszcza współmałżonków czy innych członków rodziny. Słuchać znaczy nie tylko przyjmować to, co ktoś mówi, ale przede wszystkim przyjmować tego, kto w danym momencie stoi przede mną, aby zainteresować się tym, co on teraz przeżywa, zwłaszcza kiedy jest to ostateczne i najważniejsze wydarzenie w jego życiu. Jedynie poprzez dialog, pełen zaufania i zrozumienia, można razem poszukiwać właściwych sensów życia i śmierci, otrzymać przebaczenie, przebaczając, a doświadczając miłości ze strony współmałżonka, dzieci i rodziny, z nadzieją wchodzić w inną rzeczywistośćc ${ }^{14}$.

2. Dowartościowywać przeszłość jako dziedzictwo na przyszłość - nie istnieje żadna biograficzna przeszłość w sensie całkowitej pomyłki życiowej czy bezdennej pustki. Nawet za życiem uznanym przez kogoś za bezużyteczne i bez znaczenia stoi zawsze wielki bagaż cierpień, bolesnych doświadczeń i wyborów, które powinny być ponownie zobaczone w świetle obecnie przeżywanej sytuacji, w bliskości nieuchronnej śmierci. W tym wypadku niezastąpioną rolę odgrywa rodzina, która powołując się na wspólnie przezwyciężane w przeszłości kryzysy, wskaże osobie przeżywającej stan depresji (przygotowawczej), skąd czerpała potrzebne siły i energie oraz dzięki którym, przyjętym wcześniej wartościom wychodziła zwycięsko z każdej trudnej sytuacji egzystencjalnej, małżeńskiej i rodzinnej (wspieranie, dzielenie się i wierność na dobre i na złe, stałe poszukiwanie pocieszenia i siły w wierze, życie i poświęcanie się dla dzieci).

3. Funkcja mediacyjna w reakcjach i poprzez reakcje osoby chorej - „humanizować śmierć" nie oznacza niwelować opisanych wcześniej reakcji człowieka w perspektywie zbliżającej się śmierci, bo są one w pewien sposób normalne i stanowią część procesu stopniowego przygotowywania się do stanięcia w obliczu nieznanej dotąd rzeczywistości. Humanizować tę dramatyczną dla każdego człowieka rzeczywistość znaczy przede wszystkim poszukiwać najgłębszych jej sensów celem przekształcenia negatywnych - i w wielu wypadkach nieuświadomionych reakcji w dynamiczne zasoby i środki, dzięki którym osoba chora może sprostać ekstremalnym wymogom przyspieszonego procesu dojrzewania. W tym konkretnym i bardzo osobistym wydarzeniu chodzi o stworzenie prawdziwej i właściwej struktury mediacyjnej. To niepowtarzalne wydarzenie nie jest zatem przedmiotem do opisania, lecz istotnym napięciem wewnętrznym, które niszczy równowagę człowieka w relacji do rzeczywistości uznanych do tej pory za „nieproblematyczne". W tym jedynym i niepowtarzalnym dziele stwarzania struktury mediacyjnej istotną rolę odgrywa postawa słuchania, ponieważ w dialogu i poprzez dialog można zrozumieć, co się dzieje wewnątrz osoby przeżywającej bliskość śmierci, celem

14 Por. Morente (accompagnamento), w: D. Tettamanzi, Dizionario di bioetica, Casale Monferrato: Piemme 2002, s. 285-291. 
udzielenia jej pomocy w przejściu od totalnej i niszczącej negacji do całkowitej akceptacji dramatycznych wymogów zakończenia życia ziemskiego ${ }^{15}$.

4. Postawa szacunku wobec wyborów wartości przez osobę w obliczu śmierci - jest to bardzo ważny i delikatny wymiar w posłudze chorym, który nie tylko wytycza sposób podejścia do umierającego, ale również zmusza do poszukiwania odpowiedniej formy opieki i pomocy duszpasterskiej w szpitalu. W społeczeństwach na wskroś chrześcijańskich i katolickich - takich jak Polska czy Irlandia wiara w śmierć i zmartwychwstanie Jezusa Chrystusa stanowi niezbywalną pomoc w procesie przygotowania się na śmierć. W innych społeczeństwach, bardziej zróżnicowanych światopoglądowo i religijnie, posługa duszpasterska w szpitalach jest bardzo trudnym wyzwaniem, wymagającym uszanowania innych postaw, bez radykalnej negacji jakiejkolwiek wartości pozytywnej w człowieku, który deklaruje się jako wyznawca innej wiary, niewierzący, wątpiący czy niepraktykujący. W tych przypadkach nie tylko kapelan, ale przede wszystkim rodzina i przyjaciele mogą służyć wielką i nieocenioną pomocą. Podstawową jednak zasadą w świetle Soboru Watykańskiego II jest uszanowanie wolności sumienia i osobistych wyborów: „Często jednak zdarza się, że sumienie błądzi na skutek niepokonalnej niewiedzy, ale nie traci przez to swojej godności. Nie można jednak tego powiedzieć w wypadku, gdy człowiek niewiele dba o poszukiwanie prawdy i dobra, a sumienie z nawyku do grzechu powoli ulega niemal zaślepieniu" (Gaudium et spes, 16). Niezbywalny szacunek do każdego człowieka, daleko posunięta tolerancja czy delikatna forma propozycji chrześcijańskiej wizji tajemnicy życia i śmierci nie muszą oznaczać akceptacji aksjologicznych wyborów dokonywanych przez osobę stojącą w obliczu śmierci, ale na pewno są wiarygodnym świadectwem siły prawdy, dobra i miłości, które otwierają oczy i serce na inne rzeczywistości (por. Evangelium vitae, $78-101)^{16}$.

5. Zrozumieć świat chorego - oznacza w tym przypadku widzieć świat niejako oczyma osoby chorej czy w podeszłym wieku, bez konieczności podzielania tej wizji. Byłby to po prostu mechanizm poznania i rozumienia sposobu odbierania wrażeń i reagowania na nie przez tę właśnie osobę w celu stworzenia w miarę adekwatnego obrazu psychologicznego, kulturowego, moralnego czy religijnego tego człowieka, któremu chcemy prawdziwie pomóc lub który pragnie właśnie naszej

15 Por. L. Sandrin, Wobec cierpienia, tłum. K. Kamińska, Kielce: Jedność 2000; L. Sandrin, Lo vide e non passò oltre, Bologna: EDB 2015.

16 Por. M. Petrini, Assistenza spirituale e assistenza religiosa, „Anime e Corpi” 154 (1991), s. 201-216; Conferenza dei Vescovi Cattolici d'Inghilterra e Galles, La cura spirituale del morente, „Il Regno” 15 (2010), s. 484-496; R. Fusi, La vocazione del malato nella Chiesa. Accompagnamento del malato, Roma: CVS 2010; E. Larghero, Dolore e sofferenza nell'insegnamento di Giovanni Paolo II, Torino: Edizioni Camilliane 2005; L. Manicardi, La visita al malato nella Sacra Scrittura, „Camillianum” 2 (2004), s. 363-372; L. Manicardi, Visitare i malati: approccio biblico, „Firmana” 2-3 (2005), s. 79-88; L. Di Taranto, La Cappellania Ospedaliera. Cantiere di Chiesa comunionale, San Giorgio Jonico (TA): Edizione Servi della Sofferenza 2009. 
obecności i pomocy. Oczywiście, jak zawsze, postawa wrażliwego słuchania tego, co jest przekazywane poprzez słowa (komunikacja werbalna), a w końcowym etapie poprzez gesty (komunikacja pozawerbalna), pozwoli na wnikliwsze poznanie przyczyn takich czy innych reakcji (uwarunkowania kulturowe, braki formacyjno-edukacyjne, nieuporządkowane życie moralne, małżeńskie czy rodzinne) oraz umożliwi właściwą asystencję w procesie dojrzewania (wydobywanie i podkreślanie pozytywnych wydarzeń z życia, odkrywanie racjonalnego i irracjonalnego poczucia winy i zaradzenie mu) i przygotowania się do nieuniknionego faktu śmierci (akceptacja, umieranie w spokoju).

6. Pomoc i posługa duszpasterska - szacunek i tolerancja wobec wyborów innych wartości nie oznacza, że nie należy proponować osobom umierającym czy w podeszłym wieku perspektywy wiary i nadziei chrześcijańskiej. Bóg szanuje wolność człowieka, ale i wzywa każdego w „sanktuarium sumienia” do podążania drogą prawdy, dobra i miłości. Nie inaczej może być z wierzącym przedstawicielem rodziny czy kapelanem, którzy mają ewangeliczny obowiązek głoszenia chrześcijańskiej perspektywy eschatologicznej w sposób i w formach odpowiadających wrażliwości współczesnego człowieka. „Należy ewangelizować śmierć: głosić Ewangelię umierającemu. Jest to duszpasterski obowiązek wspólnoty Kościoła, każdego z jego członków, według obowiązków każdego z nich" ${ }^{17}$. Posługa duszpasterska powinna być pomocą człowiekowi cierpiącemu w przeżywaniu i w doprowadzeniu do końca, w próbach ciężkiej choroby i w obliczu śmierci, własnego i niepowtarzalnego dzieła bycia człowiekiem: stworzonym na obraz i podobieństwo Boga oraz odkupionym przez śmierć i zmartwychwstanie Jezusa Chrystusa ${ }^{18}$.

7. Akceptacja porażek - należy być przygotowanym do zaakceptowania popełnionych błędów, przeżytych niepowodzeń i porażek, zwłaszcza w tym szczególnym okresie życia, kiedy są one częstsze i bardziej bolesne. Większa liczba egzystencjalnych niepowodzeń związana jest z obecnie przeżywanym stanem psychologiczno-duchowym, doświadczeniem ciężkiej lub nieuleczalnej choroby, a zwłaszcza nieuniknionym faktem śmierci, w którego obliczu dokonuje się końcowego bilansu życia - i nie zawsze ma on saldo dodatnie. W konsekwencji życiowe porażki przeżywa się w zwiększonej amplitudzie cierpienia, będąc świadomym nieodwracalności faktów i skończoności wszelkich przeorientowań. Przede wszystkim brak horyzontu wiary zamyka drzwi eschatologicznej nadziei przezwyciężenia granic ludzkich słabości, niepowodzeń i porażek, w której wszystko to, co ludzkie, uzyskuje sens pielgrzymki wiary, w historii zbawienia, do domu miłosiernego Ojca. Pomoc rodziny czy posługa duszpasterska wobec człowieka wierzącego,

17 Papieska Rada ds. Duszpasterstwa Służby Zdrowia, Nowa karta pracowników stużby zdrowia, Katowice: Księgarnia św. Jacka 2017, s. 131.

18 Por. Kongregacja Doktryny Wiary, List ,,Samaritanus bonus” o opiece nad osobami w krytycznych i końcowych fazach życia (14 VII 2020 r.), http://www.vatican.va/roman_curia/congregations/ cfaith/documents/rc_con_cfaith_doc_20200714_samaritanus-bonus_pl.html [dostęp: 19.01.2021]. 
przeżywającego głęboki kryzys sensu życia i wiary (depresja przygotowawcza), polegałaby na przywróceniu optyki i hierarchii wartości chrześcijańskich, na których dana osoba budowała swoje dotychczasowe życie osobiste, małżeńskie i rodzinne (pozytywna retrospektywa tych aspektów życia, odwołanie się do kryzysów przezwyciężonych dzięki wierze). W przypadku osoby niewierzącej, poważnie wątpiącej bądź niepraktykującej rodzina czy kapelan w obliczu śmierci również powinni odwoływać się do pozytywnych wydarzeń z jej życia, proponując z delikatnością i mądrością bogactwo wiary Kościoła. Sens wdzięczności za przeżyte życie i perspektywa nadziei eschatologicznej, mimo nieuniknionych błędów czy niepowodzeń, powinny stanowić pewnego rodzaju „przewodnik” do wartości, na podstawie których należałoby budować pomoc rodziny i posługę duszpasterską ${ }^{19}$.

\section{ZAKOŃCZENIE}

Długoletnie doświadczenie doktor psychologii E. Kübler-Ross przy łóżkach ludzi umierających w szpitalu Billings w Chicago pozwoliło jej przeanalizować i opisać „,proces umierania” w odniesieniu do reakcji chorych, ich bliskich, personelu medycznego i kapelanów. Na podstawie obserwacji wyróżniła ona pięć podstawowych „etapów umierania”, które zostały syntetycznie opisanie w pierwszej części artykułu. Na ich podstawie zostały następnie zaprezentowane pozytywne i negatywne reakcje i zachowania członków rodziny, a także personelu medycznego i kapelanów. Dokonana retrospekcja pozwoliła nakreślić podstawowe kryteria prawidłowych i bardziej odpowiedzialnych zachowań wobec osób stojących w obliczu nieuniknionej śmierci. Na zakończenie refleksji zostały wskazane istotne elementy „etyki końca życia”, które powinny pomóc osobom obecnym przy umierających, zwłaszcza kapelanom i duszpasterzom, w bardziej świadomym i odpowiedzialnym podejściu do ludzkiego mysterium mortis, przeżywanego w rodzinie, szpitalu i parafii.

19 Por. Commissione Episcopale per il Servizio della Carità e la Salute, Predicate il vangelo e curate i malati. La comunità cristiana e la pastorale della salute, Bologna: EDB 2006; A. Rizzi, L'uomo di fronte alla morte, Villa Verucchio (RN): Pazzini 2006, s. 63-82; A. Brusco, S. Pintor, Sulle orme di Cristo medico. Manuale di teologia pastorale della salute, Bologna: EDB 2008; F. Cancelli, Vivere fino alla fine. Accompagnamento e cura della persona morente, Torino: Lindau 2012; G. Russo, Il medico. Identità e ruoli nella società di oggi, Roma: Elle Di Ci 2004; S. Leone, Manuale di Bioetica, Acireale: ISB 2003, s. 191-247; Fundacja TZMO - Razem Zmieniamy Świat, Projekt Damy Radę. Towarzyszenie osobie umierającej, https://damy-rade.info/ [dostęp: 7 V 2021]. 


\section{TOWARZYSZENIE OSOBIE UMIERAJĄCEJ PRZEZ RODZINĘ. ETYKA KOŃCA ŻYCIA}

\section{Streszczenie}

Przedmiotem artykułu jest ,,proces umierania” kogoś bliskiego przeżywany przez niego samego, jego rodzinę i personel medyczno-sanitarny, opisany i przeanalizowany przez doktor psychologii Elisabeth Kübler-Ross. Najpierw zostały przedstawione reakcje pacjenta w obliczu śmierci: odrzucenie i odosobnienie, gniew i bunt, kompromisy i pakty, depresja i akceptacja. W dalszej części opisano reakcje rodziny w obliczu perspektywy śmierci: etap odrzucenia i odosobnienia, etap gniewu i buntu, etap zgody na kompromisy i zawieranie paktów, etap przeżywania depresji, etap akceptacji. Na zakończenie zostały nakreślone istotne elementy „etyki końca życia”, które powinny pomóc w bardziej świadomym i odpowiedzialnym podejściu do mysterium mortis. Elementami tymi są: postawa słuchania, dowartościowanie przeszłości jako dziedzictwo na przyszłość, funkcja mediacyjna w reakcjach i poprzez reakcje osoby chorej, postawa szacunku wobec wyborów wartości przez osobę w obliczu śmierci, zrozumienie świata chorego, pomoc i posługa duszpasterska, akceptacja porażek.

Słow a klu c zow e: etyka końca życia, Kübler-Ross, śmierć, personel sanitarny, umieranie.

\section{ACCOMPANYING A DYING PERSON BY THE FAMILY. END OF LIFE ETHICS}

\section{Summary}

The object of the article is the "dying process" of a dear one, as lived by himself, his family, and the medical personnel, and as described and analyzed by the psychologist Elisabeth Kübler-Ross. First, the patient's reactions to death were presented: denial and isolation, anger and rebellion, bargaining, depression, and acceptance. The next part describes the reactions of the family in the face of the prospect of death: the stage of rejection and isolation, the stage of anger and rebellion, the stage of compromise and making pacts, the stage of experiencing depression, and the stage of acceptance. At the end of our reflection, we indicated the essential elements of an "end of life ethics", which would permit us to approach, in a more conscious and responsible manner, "our" mysterium mortis at a personal level, in the family and in hospital. These elements are: the attitude of listening, valuing the past as a legacy for the future, the mediation function in and through the reactions of the sick person, the attitude of respect towards the person's choices of values in the face of death, understanding the sick world, help and pastoral service, and acceptance of failures.

K e y w ord s: end-of-life ethics, Kübler-Ross, death, health workers, dying. 


\section{BEGLEITUNG DER STERBENDEN PERSON DURCH DIE FAMILIE. ETHIK AM ENDE DES LEBENS}

\section{Zusammenfassung}

Das Thema dieses Artikels ist der Sterbeprozess eines Menschen, wie er von ihm, seinen liebenden Angehörigen und dem medizinischen Personal erlebt wird. Beschrieben und analysiert wird dieser Prozess von Elisabeth Kübler-Ross, der bekannten Psychologin und im Sterbeforscherin. Zunächst werden die Reaktionen des Patienten im Angesicht des Todes dargestellt: Ablehnung und Isolation, Wut und Rebellion, Kompromisse und Verhandlungen, Depression und Akzeptanz. Dann werden die Reaktionen der Familie angesichts des Todes des lieben Angehörigen beschrieben: das Stadium der Ablehnung und Isolation, das Stadium der Wut und Rebellion, das Stadium des Einverständnisses mit Kompromissen und der Schließung von Pakten, das Stadium des Erlebens von Depression, das Stadium der Akzeptanz. Am Ende der Überlegungen werden die wesentlichen Elemente einer „Ethik des Lebensendes"skizziert, die uns helfen sollen, bewusster und verantwortungsvoller mit unserem eigenen mysterium mortis umzugehen, das dann in der Familie und im Krankenhaus gelebt wird. Diese Elemente sind: eine Haltung des Zuhörens, eine Wertschätzung der Vergangenheit als Vermächtnis für die Zukunft, eine vermittelnde Funktion in und durch die Reaktionen der kranken Person, eine Haltung des Respekts für die Wertewahl der Person angesichts des Todes, das Verständnis für die Weltsicht der kranken Person, Beistand und Seelsorge sowie Akzeptanz von Misserfolgen.

S c hlü s s e lw ört e r: Ethik am Lebensende, Kübler-Ross, Tod, Gesundheitsberufe, Sterben.

\section{BIBLIOGRAFIA}

Association EKR France, https://www.ekr-france.fr/ [dostęp: 7 V 2021].

Belkin G.S., Death before Dying, Oxford-New York: Oxford University Press 2014.

Brusco A., Pintor S., Sulle orme di Cristo medico. Manuale di teologia pastorale della salute, Bologna: EDB 2008.

Cancelli F., Vivere fino alla fine. Accompagnamento e cura della persona morente, Torino: Lindau 2012.

Commissione Episcopale per il Servizio della Carità e la Salute, Predicate il vangelo e curate i malati. La comunità cristiana e la pastorale della salute, Bologna: EDB 2006.

Conferenza dei Vescovi Cattolici d'Inghilterra e Galles, La cura spirituale del morente, „Il Regno” 15 (2010), s. 484-496.

Di Taranto L., La Cappellania Ospedaliera. Cantiere di Chiesa comunionale, San Giorgio Jonico (TA): Edizione Servi della Sofferenza 2009.

Dzierżanowski T., Binnebesel J., Godność w umieraniu, „Medycyna Paliatywna” 11 (2019), nr 4, s. 156-162. 
EKR Foundation, https://www.ekrfoundation.org/ [dostęp: 7 V 2021].

Fundacja TZMO - Razem Zmieniamy Świat, Projekt Damy Radę. Towarzyszenie osobie umierajacej, https://damy-rade.info/ [dostęp: 7 V 2021].

Fusi R., La vocazione del malato nella Chiesa. Accompagnamento del malato, Roma: CVS 2010.

Kępińska-Walczak Z., Recenzja książki „Rozmowy o śmierci i umieraniu” autorstwa Elisabeth Kübler-Ross. Poznań 1998, wyd. Media Rodzina, „Warszawskie Studia Pastoralne” 19 (2013), s. 339-344.

Kongregacja Doktryny Wiary, List ,, Samaritanus bonus” o opiece nad osobami w krytycznych i końcowych fazach życia (14 VII 2020 r.), http://www.vatican.va/roman_curia/ congregations/cfaith/documents/rc_con_cfaith_doc_20200714_samaritanus-bonus_ pl.html [dostęp: 19 I 2021].

Kowalski E., Osoba i bioetyka. Zagadnienia biomedyczne dla duszpasterzy i katechetów, Kraków: Homo Dei 2009.

Kübler-Ross E., Impara a vivere impara a morire. Riflessioni sul senso della vita e sull'importanza della morte, Milano: Armenia 2001.

Kübler-Ross E., La morte è di vitale importanza. Riflessioni sul passaggio dalla vita alla vita dopo la morte, Milano: Armenia 1997.

Kübler-Ross E., La morte e il morire, Assisi: Cittadella ${ }^{15} 2009$.

Kübler-Ross E., La morte e la vita dopo la morte. „Morire è come nascere”, Roma: Edizioni Mediterranee 2007.

Kübler-Ross E., Lezioni di vita. Ciò che la morte e il morire ci insegnano sulla vita e sul vivere, Torino: Edizioni L'Età dell'Acquario 2019.

Kübler-Ross E., On Death and Dying: What the Dying Have to Teach Doctors, Nurses, Clergy and Their Own Families, London and New York: Routledge. Taylor \& Francis Group 2009.

Kübler-Ross E., Pytania i odpowiedzi na temat śmierci i umierania. Odpowiedzi na najczęściej zadawane pytania dotyczące śmierci, tłum. K. Sobiepanek-Szczęsna, Warszawa: MT Biznes 2010.

Kübler-Ross E., Rozmowy o śmierci i umieraniu, tłum. I. Doleżal-Nowicka, Poznań: Wydawnictwo Media Rodzina 1998.

Kübler-Ross E., Sulla vita dopo la morte, Torino: Edizioni L'Età dell'Acquario 2018.

Kübler-Ross E., Śmierć. Ostatni etap rozwoju, tłum. K. Sobiepanek-Szczęsna, Warszawa: MT Biznes 2019.

Kübler-Ross E., Vivi ora e oltre la morte, Roma: Edizioni Mediterranee 2016.

Kübler-Ross E., Kessler D., Lekcje życia, tłum. K. Pułaski, Poznań: Wydawnictwo Media Rodzina 2014.

Larghero E., Dolore e sofferenza nell'insegnamento di Giovanni Paolo II, Torino: Edizioni Camilliane 2005.

Leone S., Manuale di Bioetica, Acireale: ISB 2003.

Liguori A.M. de', Apparecchio alla morte cioè considerazioni sulle massime eterne, Cinisello Balsamo (Mi): Edizioni San Paolo 2011.

Liguori A.M. de', Przygotowanie do śmierci, tłum. J. Serafin, Kraków: Homo Dei ${ }^{2} 2016$.

Manicardi L., La visita al malato nella Sacra Scrittura, „Camillianum” 2 (2004), s. 363-372.

Manicardi L., Visitare i malati: approccio biblico, „Firmana” 2-3 (2005), s. 79-88. 
Niemiec M., Aspekty etyczne dotyczace końca życia. Ethical aspects of the end of life, „Medycyna Paliatywna w Praktyce” 10 (2016), nr 1, s. 1-7.

Papieska Rada ds. Duszpasterstwa Służby Zdrowia, Nowa karta pracowników służby zdrowia, Katowice: Księgarnia św. Jacka 2017.

Petrini M., Assistenza spirituale e assistenza religiosa, „Anime e Corpi” 154 (1991), s. 201-216.

Rizzi A., L'uomo di fronte alla morte, Villa Verucchio (RN): Pazzini 2006.

Russo G., Il medico. Identità e ruoli nella società di oggi, Roma: Elle Di Ci 2004.

Sandrin L., Lo vide e non passò oltre, Bologna: EDB 2015.

Sandrin L., Wobec cierpienia, tłum. K. Kamińska, Kielce: Jedność 2000.

Stanford Center for Biomedical Ethics, https://med.stanford.edu/bioethics/events/elisabeth-kubler-ross-archive.html [dostęp: 7 V 2021].

Taranto L. di, La Cappellania Ospedaliera. Cantiere di Chiesa comunionale, San Giorgio Jonico (TA): Edizione Servi della Sofferenza 2009.

Tettamanzi D., Dizionario di bioetica, Casale Monferrato: Piemme 2002.

Vella C.G., L'etica a servizio della persona malata. Esperienze e riflessioni maturate al San Raffaele di Milano, Milano: Edizioni Paoline 2007.

Wiśniewska-Roszkowska K., Starość jako zadanie, Warszawa: PAX 1989.

Edmund Kowalski - duchowny Kościoła rzymskokatolickiego (redemptorysta), od 1998 roku profesor Accademia Alfonsiana - Istituto Superiore di Teologia Morale w Rzymie. Studiował w Warszawie (ATK - UKSW), Paryżu i Waszyngtonie. Autor publikacji w dziedzinie etyki, bioetyki i teologii moralnej. W ostatnim czasie opublikował między innymi książki Człowiek $i$ bioetyka (2009), Osoba i bioetyka (2015). Adres do korespondencji: ekowalski@libero.it. 